\title{
MAINALI'S “A BLAZE IN THE STRAW” AS A FINE WORK OF ART
}

\author{
Rudra Prasad Paudel ${ }^{*}$
}

\begin{abstract}
Art refers to the product of creative human activity in which concepts are shaped and selected to convey an idea or emotion. A short story is an art form, a particular type of artistic activity and a product of the author's imagination. Unlike novels that usually depict conflicts among many characters, developed through a variety of episodes, stimulating a complexity of responses in readers, a short story is a brief fictional narrative prose disclosing one character's inner conflict with others having one thematic focus. It concisely presents events and stirs our imagination.
\end{abstract}

Guru Prasad Mainali (1900-1971), one of the prominent writers and a leading personality in Nepali literature, develops the modern short story in Nepali language and becomes popular with a few stories. His most famous stories have been collected in The Ward (Naso) (1969) in which an elderly Brahman who has no children is obliged to marry a second wife in order to clear his way to paradise. He writes stories in a new model and each is considered a classic. He is a modern artist in Nepali short story writing. In "A Blaze in the Straw," Mainali focuses on a way of living of husband and wife in Nepali context and proves that the quarrel between husband and wife is not more than a blaze in the straw as shown in the life of Chame and Gaunthali. He, very skillfully, expresses the experience of the characters as it is, which is the greatness of the artist suggested in the art. Based on this fact, this article discusses Guru Prasad Mainali as a modern artist and his "A Blaze in the Straw" as Nepali proverb implied in the title.

\section{HISTORICAL BACKGROUND OF SHORT STORY}

The modern short story develops out of earlier types of fiction in prose and verse. Its ancestors are the ancient tales, fables and simple stories, each with a lesson. There were also popular Greek and Asian stories of magical transformations with moralistic, satirical and pure entertainment aims. The people of that time collected the stories and retold for their purposes such as spending time, getting enjoyment, educating, etc. One of the most popular collections of the short stories from Persia, Arabia, India and Egypt is Arabian Nights in which the beautiful queen Scheherazade entrances her husband, the Sultan, with a new tale every evening, leaving the suspenseful ending for the next day so he will not carry out his vow to kill her. Similarly, the tales of Akbar and Birbal, Aesop's fables, Romance tales in France, and The Canterbury Tales by Geoffery Chaucer are the earliest ancestors of the modern short stories. Likewise, The Veda, The

\footnotetext{
*Associate Professor, Ratna Rajyalaxmi Campus,Tribhuvan University, Kathmandu, Nepal
} 
Ramayana, The Mahabharata and The Koran are full of wonderful short stories, which modern writers reiterated. "Indeed The Old Testament has been called 'the unread best seller" (Ress 1990) shows that though the short story did not reach the height of its popularity until the beginning of the $20^{\text {th }}$ century, it is one of the oldest types of literature.

Although the people told and retold the fables, epics about beasts, religious tales, romances, fabliaux or ribald tales and legends, they were not published until the $18^{\text {th }}$ century. One source of published stories was the English magazine The Spectator edited by Joseph Addison and Sir Richard Steel. "In the $18^{\text {th }}$ century, Steel and Addison evolved the tale-with-a-purpose to drive home a moral, but this again is different from the present-day tale of 'impression' or 'idea,', (Prasad 1965). Upto that time, the primary focus of most stories had been on the plot.

The short story is a favorite form of present day writing. In the history of short story writing in Nepal, Guru Prasad Mainali, Bishweshwar Prasad Koirala, Bhavani Bhikshu, Bijaya Malla. Shanker Lamichhane, Poshan Pandey, to name a few, are legendary figures to contribute and develop the modern short story contribution and develop the modern short story writing in Nepali literature. The popularity of this genre has grown and spread here because these authors meet the needs and purposes of Nepali readers in the constantly changing Nepali context.

\section{LENGTH AND DEFINITION}

Compared to other genres, in length story is a recent development in literature. Simply, a story, which is short, is called short story. But how short is it? There is no demarcation line between the long short story and the short novel called novella. Abut the length, Rees says, "The shortest of short stories may be no more than a page or two in length; the longest, like D.H. Lawerence's St Mawr for example, may run to over a hundred pages”. It clearly shows us that a short story, a fictitious prose narrative in which characters and actions are portrayed in simpler plot and less varied setting, is shorter than a novel. Oxford Advanced Learner's Dictionary defines it as, “a story, usually about imaginary characters and events, that is short enough to be read from beginning to end without stopping" (Hornby 2010). In the same manner, Frederic Raphael argues, "The charm of the short story lies in its density, which is composed principally by a certain (elusive) sense of the author's experience and weight, the richness of his or her knowledge of the world, distilled in narrow confines” (qtd. in Markham 1988). Edgar Allan Poe, who is sometimes called the originator of the short story as a specific genre, and a master of short fiction, believes that short story writers could create interesting characters, a rich setting and a strong plot with economy and brevity. He calls a short story "a prose tale" and defines it ... as a narrative that can be read at one sitting of from one-half to two hours, and that is limited to a certain unique or single effort to which every detail is subordinate" (qtd. in Abrams 1993). This definition points to the economy of organization, which the tightness of the form always imposes in some degree. In a short story, a central incident is selected to reveal as much as possible of the totality of the protagonist's life and character, and the details are devised to carry maximum significance. Here, it is worth quoting H.G. Wells: 
A short story is, or should be, a single thing; it aims at producing one single vivid effect; it has to seize the attention at the outset, and never relaxing, gather it together more and more until the climax is reached. The limits of the human capacity to attend closely therefore set a limit to it: must explode and finish before interruption occurs or fatigue sets in (qtd. in Ress 1993).

In this sense, a short story is complete in itself. It has unity of impression or idea to communicate from the first to the last sentence.

Similarly, Laxmi Prasad Devkota compares short story with a small window. He says, "A short story is a small window through which a small world is peeped out..." (qtd. in Shrestha 2001). In fact, short story is one of the oldest forms of literature though it did not reach the height of its popularity until the beginning of the twentieth century. In this regard, it is significant to quote Somerset Maugham's words, "From the beginning of history men have gathered round the camp fire or in a group in the market place, to listen to the telling of a story" (qtd. Shrestha 2001) Mainali's story covers and meets these definitions. Appreciating this story as a fine work of art, Dayaram Shrestha maintaions, "He [Mainali] has written only eleven stories. Out of them, 'A Blaze in the Straw' in one of the best artistic creations of Nepali literature. This story establishes his ideal form of story writing skill” Although he writes a few short stories, his knowledge of Nepali people makes him an excellent exponent of the life in the hills and mountains. Indeed, this story is a type of art of literature by which Mainali gets excellence and becomes a successful story-writer.

\section{“A BLAZE IN THE STRAW”: FINE WORK OF ART}

The short stories before Mainlai were miraculous, magical, extremely sentimental and unorganized. They were unreal, mythological and supernatural based on fairies, witches, sorceries, black arts and magic. The storytellers evoked the life of men with the ancient feeling of the cosmic mystery, the pre-human and unhuman power of the universe fantastically. Mainali transforms that tendency and leads the short story writing toward realistic ground with conscious organization. He portrays realistic picture of Nepali life using exact Nepali colloquial expression. His characters speak language as per their level. They are true-to-life characters who at the end, realize their mistake and choose the track from realism to idealism giving a moral message to the readers.

"A Blaze in the Straw" is not just a report of events. It is short fiction based on the writer's imagination. However, although fiction is "anything made up," this story has its roots in life and writer's experience. In this work of art, the storywriter, with care and skill, paints a picture of the real Nepali rural society. He takes a plot and fits characters to it, chooses incidents and situations to develop it, takes a certain atmosphere, and gets actions and persons to realize it. Mainali considers that he must have an impression or idea to communicate his readers. As well-organized work of art, this story is made up of the basic elements of short fiction: plot, characters, setting, point of view and theme. These elements are tightly woven like a spider's web in this short story and make it aesthetically pleasing.

This story has a strong plot. The plot of the story is made up of a series of related events that include conflict, climax and resolution. The conflict is a 
struggle between opposing people or forces. It intensifies until it reaches a climax, the turning point at which the conflict is confronted head-on. It is the point of highest interest. The resolution shows how the situation turns out and ties up loose ends. In the beginning of the story, the writer provides the background information, called exposition in which the situation is revealed. It sets the scene for the conflict. The rest of the story is devoted to the resolution of the struggle. Here, Mainili exposes that Chame and this wife Gaunthali are poor, uneducated villagers. Gaunthali is a sharp-tongued woman who slants any issue of the family and begins to quarrel about. "Every few days man and wife would quarrel" (1993) As the story proceeds, this information introduces complication. One evening when Chame comes home from his ploughing he finds the house locked and Gaunthali gone to the village to watch a wedding. After a whole day of ploughing, he is tried and hungry. This complication causes the conflict when Gaunthali comes home. Chame flares up in anger. They quarrel abusing each other with peculiar Nepali expressions like, "This old widow's spent the whole day making eyes at the men and still she's putting on airs". Gaunthali is not less. She also uses the words "butcher", "destitute corpse", etc. to her husband. Immediately, their conflict reaches its height. As a male of the village maledominated Nepali society, the husband scolds his wife, "Don't stay another second in my house! Get out and go where you will!" by dragging her out by her pigtail and throws her into the yard. In the pattern of action, events are interconnected to one another in time and space as well as in terms of cause and effect. As the effect of the quarrel, Gaunthali packs up her clothes and goes off to her parent's home leaving her husband. This is the climax of the story. This climax prolongs and creates a tension in Chame's mind. Mainali is able to interlace the sequence of events before the story's resolution. Chame's life in the absence of Gaunthali becomes harder than before. The buffalo incidents, Kokale's mother's swearwords "Chame, may you become a barren corpse! A corpse that not even cholera can carry off! Yesterday you beat your wife, and today you beat your buffalo and destroy somebody else's income for the year!”, the reaction and teasing of his neighbors, such as Juthe and his wife while fetching water from a spring "Oh, how bad it looks when a man fetches water!" and their suggestions to bring back Gaunthali with a realization not only creates a psychological tension in him but also create the turning point of the narrative. At his most, his mind exercises for the further action. Finally, he finds a solution. He puts on his best clothes, goes to his in law's house and brings his wife back home. The pattern of the plot of this story contains a beginning, middle and an end. The focus of interest is on the course and outcome of the events.

Also central to this short fiction short fiction is characterization. Characters are, of course, the people, or sometimes the animals, that take part in the events. They are judged from their disposition and motivation. They are sometimes described as being round or flat. Round characters are like real people. They reveal several aspects to their personality, and grow and change as the story develops. Flat characters are one-dimensional, often revealing a single personal quality and staying the same throughout the story. Chame and Gaunthali are the central characters in this story. They are representative of Nepali rural society. 
They are extrovert and round characters. They, not in haste, but gradually develop, realize their weaknesses and change their concept guided by social ethics and norms. The change in Chame motivates him to bring his wife back home.

Gaunthali also changes her mind and compromises with him short story. Mainali is successful in creating the representative, life-like characters in this fiction. He is able to make them express their inner thoughts and feelings. For instance, when Chame reaches near his in-law's house he sits at a Chautara and wipes his sweat from his brow. At that moment, he Gaunthali's inner feeling which she expresses through a song while carrying down a bundle of cut grass, "I would fly away, but I am no bird, I cannot bear to stay". Here, the storywriter shows us how it is difficult for a Nepali married woman to stay at her parents' home. In fact, due to his contact with different kinds of people in different parts of the country as a judge transferred from one district court to the other, Mainali has an adequate opportunity to study the human character in various situations closely. The exposition of the desperate predicament of the common people in Nepalese context is also relevant at present. Experience of the characters is very credible in this story.

Realistic setting is another excellence of this story. It is set in a Nepali village. The time and place in which the action of the narrative occurs provide a background for the story's action. The rural setting where the characters grow, events happen seem to be convincing. Mainali is alert about time. "One evening”. "The next morning”, “during the first week after his wife's departure”, "after dusk had fallen", "after the evening meal”, "it was time to let the animals out”, "the sun was setting behind the hills, Cowherds were driving their cows home in a cloud of dust, moving slowly up the slope", etc. are notable time indicators which demonstrate the way of villagers' to point out the time in this story. His awareness of time makes us understand the story easily.

Another component of narrative is point of view. It is the angle of perspective from which the story is told. In this story, there is third person narrator, a voice outside the story, "When she [Juthe's wife] saw Chame, she stuck our her tongue. Then she laughed and said, "oh, it looks like a goose and gander with the bride out in front and the groom behind!'”. Here, Mainali creates the omniscient narrator, all-seeing and all-knowing, who enters the minds of all characters and tells us what they think and feel and how they view events. This narrator tells us things that the characters in the story do not know.

Theme is the central idea of a story or insight into life that is revealed through the events. The theme of "A Blaze in the Straw" is implied in the title. The way that the protagonist in a story changes and grows often can be a key to the theme. In this story, Chame goes to bring Gaunthali back home because of change in him. Gaunthali is ready to go with him. They both have realization. The expression of Juthe's wife at the end of the story, “Oh, it won't be long before you quarrel again! But a squabble between a man and his wife is just a blaze in the straw!”, is the key statement and hence the central theme. The writer presents 
the way of living of husband and wife. In fact, the quarrel between husband and wife is temporary like the blaze in the straw.

\section{A SUMMING UP}

Mainali, the pioneer of social realism in modern Nepali short fiction, reveals the real social conditions of Nepali rural people and makes clear the Nepali proverb through this work of art. The expression of the experience of speakers is very credible here. In fact, Mainali has the capacity to capture the real experience of the characters and to the capacity to capture the real experience of the characters and to emit their inner out. This work of art is based on realism; it has no place for sentimentalism. Very clearly, the writer is able to express the pathetic aspect of rural life and expose the problematic social situations implied in them with compact and economy of language in an organized linear pattern. He uses the apt words and telling phrases. Every word contributes to its effect. The form of this story also produces indulgence in stylistic elegance. His style is clear and simple that produces a specific effect on the reader. Brevity, clarity, realistic pithy dialogue and lively depiction of Nepali rural life-style are some of his features. In this respect, he is not only an entertainer but also an inventor. In fact, the art of short story is its aesthetic excellence that can touch the human heart. Having these qualities, Mainali enlightens as well as entertains the readers through this memorable work of art. Undeniably, this is the purpose of an artist to create the art.

\section{WORKS CITED}

Abrams, M. H. 1993. A Glossary of Literary Terms. (Seven edition). Harcourt College, Delhi:

Mainali, G. P. 1993. A Blaze in the Straw. Himalayan Voices: An introduction to Modern Nepali literature. Motilal Banarasidass.

Markham, E. A. (editor) 1998. Caribbean Short Stories. Penguin Books, London.

Hornby, A. S. et al. (editors) 2010. Oxford Advanced Learner's Dictionary. (Eight edition) Oxford University Press, Oxford.

Prasad, B. 1965. A Background to the Study of English Literature. MacMillan, New Delhi.

Rees, R.J. 1990. English Literature. MacMillan, Madras.

Shrestha, D. (editor). 2001. Oralic Nepali Katha (Bhanga 4). Sajha Prakashan, Lalitpur. 